\title{
Den arabiske roman fra 1980'erne og frem
}

\author{
Nogle tilbagevendende motiver
}

Nærværende artikel undersøger arabiske romaner fra 1980'erne og 1990'ere (samt nogle få fra de tidlige 2000'ere) i lyset af en alternativ beskrivelse af det, man har kaldt 'postmodernismen'. ' Det anføres, at de beskrivende kategorier, der er udviklet på grundlag af europæiske tekster, også giver mening i forhold til tekster fra Mellemøsten og Nordafrika, idet det hævdes, at den måde, livet opleves på i disse regioner i slutningen af det 20. og begyndelsen af det 21. århundrede, ikke adskiller sig grundlæggende fra den måde, det opfattes på i Vesten - der er et globalt diskursivt fællesskab med ens syn på livet på begge sider, snarere end et 'civilisationernes sammenstød'. Den alternative beskrivelse tildeler mange 'postmoderne' træk en plads i en tredelt 'betydnings-struktur', der kaster nyt lys over den pågældende periodes indre arkitektur og den funktion, de enkelte dele har i helheden.

\section{Indledning}

Det er generelt accepteret, at den moderne arabiske litteratur undergik fundamentale forandringer efter nasserismens sammenbrud i 1960'erne og især efter de arabiske styrkers nederlag i Seksdageskrigen i juni 1967. Som i anden mellemøstlig litteratur (tyrkisk, persisk), men også samtidig med den næsten verdensomspændende udvikling, hvor de yngre generationers (først og fremmest studenternes og de intellektuelles) bevægelser i 1960'erne omstyrtede de traditionelle autoriteter, var paradigmeskiftet, også hvad angik de litterære paradigmer, så omfattende, at man hurtigt begyndte at føle, at man reelt var trådt ind i en 'ny tid' i historien. Mens de politiske og sociale forandringer gradvist fik vind i sejlene i 1970'erne i kølvandet på krigen i 1967, blev den nye æras særpræg til sidst så gennemtrængende og dominerende, at litteraturkritikere henimod slutningen af 1970'erne forsøgsvis begyndte at udbrede dem og sætte dem i system som træk ved en ny periode i litteraturhistorien. Den term, der inden for den arabiske litteratur nok blev den bredest accepterede, når man skulle beskrive den nye periode, var Idwār (Edward) al-Kharrāțs 'ny føl- 
somhed' (hassāsiyya jadīda). Til trods for den kendsgerning, at al-Kharrāt imidlertid allerede havde bemærket, at forandringerne i de litterære paradigmer ikke blev indført i den arabiske litteratur isoleret fra samtidige strømninger i Vesten, såsom magisk realisme eller den franske nouveau roman, blev arabisk litteratur stadig betragtet som en afgrænset størrelse, der fulgte sit eget spor. Det var først Arabische Literatur, postmodern, en samling essays redigeret i 2004 af et hold tyske arabister, ${ }^{2}$ der ikke kun hævdede, at moderne arabisk litteratur fra 1980'erne og 1990'erne kunne ses som hørende, om end på sin egen underfundige måde, til den verdensomspændende strømning eller bevægelse, der var kendt som 'postmodernismen', men også var i stand til at få en større læserskare til at bemærke denne påstand, i det mindste i de tysktalende lande. ${ }^{3}$ I modsætning til al-Kharrāțs term 'hassāsiyya jadīda' fik en sådan 'vestlig' rubricering ikke lov til at gå ubeagtet hen. Ved en workshop om 'Postmodernismen og tiden derefter', der blev afholdt i Uppsala i juni 2008, ${ }^{4}$ blev brugen af termen 'postmodernisme' om arabisk litteratur genstand for en ophedet debat blandt 'universalister' og 'partikularister'. De førstnævnte gik ind for at integrere den arabiske 'ny følsomhed' (al-Kharrāț term) og dens arvtager, litteraturen fra den såkaldte 1990'er-generation, i 'postmodernismens' terminologiske område, et område, der indtil da udelukkende havde været begrænset til 'vestlig' litterær produktion. De sidstnævnte insisterede på 'den arabiske mådes' specificitet, idet de fremhævede forskellen mellem arabisk og vestlig litterær produktion og advarede imod faren for at overse visse ikke-vestlige kendetegn, hvis arabisk litteratur blev beskrevet med en periodisk terminologi udviklet udelukkende på grundlag af vestlige tekster.

Nærværende artikel forsøger at omgå dette terminologiske dilemma ved at tage den alternative terminologi, og det underliggende alternative syn, i brug, som blev brugt af nu afdøde Walter Falk, der var professor i germansk litteratur ved Universitetet i Marburg. Ligesom Neuwirth/Pflitsch/Wincklers brug af termen 'postmodernisme' i Arabische Literatur, postmodern, er også Falks tilgang og terminologi universalistisk. Jeg er imidlertid ganske overbevist om, at dette ikke kun er en berettiget, men også en nødvendig indstilling, eftersom al mellemøstlig litteratur fra det 19. århundrede og frem, og med tiltagende intensitet, er gået igennem en progressiv proces, der har ført til integration med den litterære udviklings globale forløb, 5 og hvis man skal acceptere dette, er der behov for en terminologi, der gør det muligt at se både vestlig og østlig litterær produktion under ét - som specifikationer på ét og samme niveau af mere generelle, globale strømninger. Falks tilgang har muligvis den ulempe, at den introducerer et helt nyt sæt termer, men dens store fordel og held er, at den undgår terminologisk sammenblanding med eksisterende periodisk 'ordforråd'. Det er korrekt, at teorien først blev udviklet udelukkende på grundlag af tyske tekster; i mellemtiden er den dog blevet testet med succes på en hel del tekster fra ikke-vestlige litteratur, blandt andet arabisk litteratur (egyptisk). ${ }^{6}$ Da Falks og hans teams analyser af egyptiske romaner især har koncentreret sig om perioden før 1967, bliver det interessant at se, hvordan tilgangen kan udvides til senere perioder. Netop Falks systems anvendelighed på arabisk litteratur fra slutningen af det 20. og begyndelsen af det 21. århundrede vil dernæst yderligere påvise et faktum, der længe har været tilsidesat, nemlig at kalendere i Mellemøsten ikke viser en an- 
den tid end i Vesten, og at livet grundlæggende opleves på meget ens måder på alle sider af Middelhavet. Hans tilgang giver desuden et redskab til at ordne og gruppere hidtil isolerede data og forståelser under én overskrift i et system, der på samme tid gør det muligt at tildele de mange betydningselementer hver deres specifikke plads inden for en hel velorganiseret struktur. ${ }^{7}$

For så vidt angår den tyske litteratur efter 1980, fandt Walter Falk en alternativ, måske lidt finurlig term for at karakterisere den periode, det i den grad var blevet på mode at benævne 'postmodernisme'. Han kaldte den forsøgsvis 'malisme' (Malismus), et ord dannet ud fra det latinske malum, det vil sige det 'onde'. ${ }^{8}$ Falk valgte denne term, fordi han identificerede 'det Onde' (forstået meget bredt) som liggende til grund for en tredelt struktur, ${ }^{9}$ der var fælles for alle de tekster, han havde studeret. Den vigtigste og følgelig eponyme, strukturelle komponent i malistiske tekster er, siger han, heltens konfrontation med, hvad man med en metafor kan beskrive som et 'hus', som i tidligere tider har givet et hjems tryghed og varme, men som nu ligger i ruiner, ødelagt af 'onde' kræfter, der i de fleste tilfælde har noget djævelsk over sig og nogle gange endda personificeres som Satan selv. Den anden komponent, på en måde antitese i den aktuelle situation præget af 'ødelæggelse', som helten står over for, er en slags 'skat', som han finder i 'ruinerne', en 'skat', som tydeligvis (og forhåbentlig) har overlevet al ødelæggelse uden skader og derfor indtager Potentialitetens plads i Falks PAR-struktur (potentialitet-aktualitet-resultativitet). Den tredje komponent - lad os bare kalde den en syntese - omfatter resultaterne af heltens bestræbelser på at bjærge Skatten fra Ruinerne, mod det Ondes kræfter. ${ }^{\text {IO }}$ (Se Figur 1).

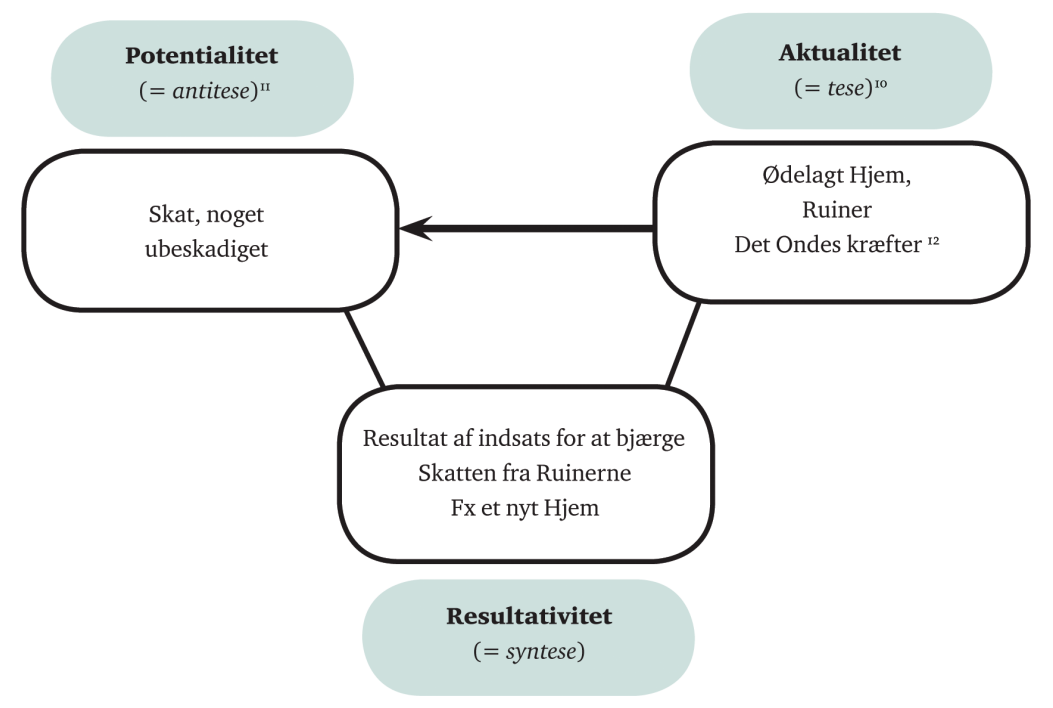

Figur 1: PAR-meningsstruktur i tekster fra den malistiske periode (1980 ff.) ifølge W. Falk. 
Når man ser på diagrammet, giver det sig selv, at Falks model er struktureret i et system i langt højere grad end den sædvanlige term 'postmodernisme', som bare er en overskrift, under hvilken de karakteristiske træk ved det aktuelle bliver subsumeret på en rent additiv, ustruktureret måde. Det er imidlertid heller ikke svært at systematisere 'postmodernismen' efter Falks malisme-model. Figur 2 viser, hvordan nogle af de vigtigste postmoderne træk kan placeres i forhold til de tre malistiske komponenter.

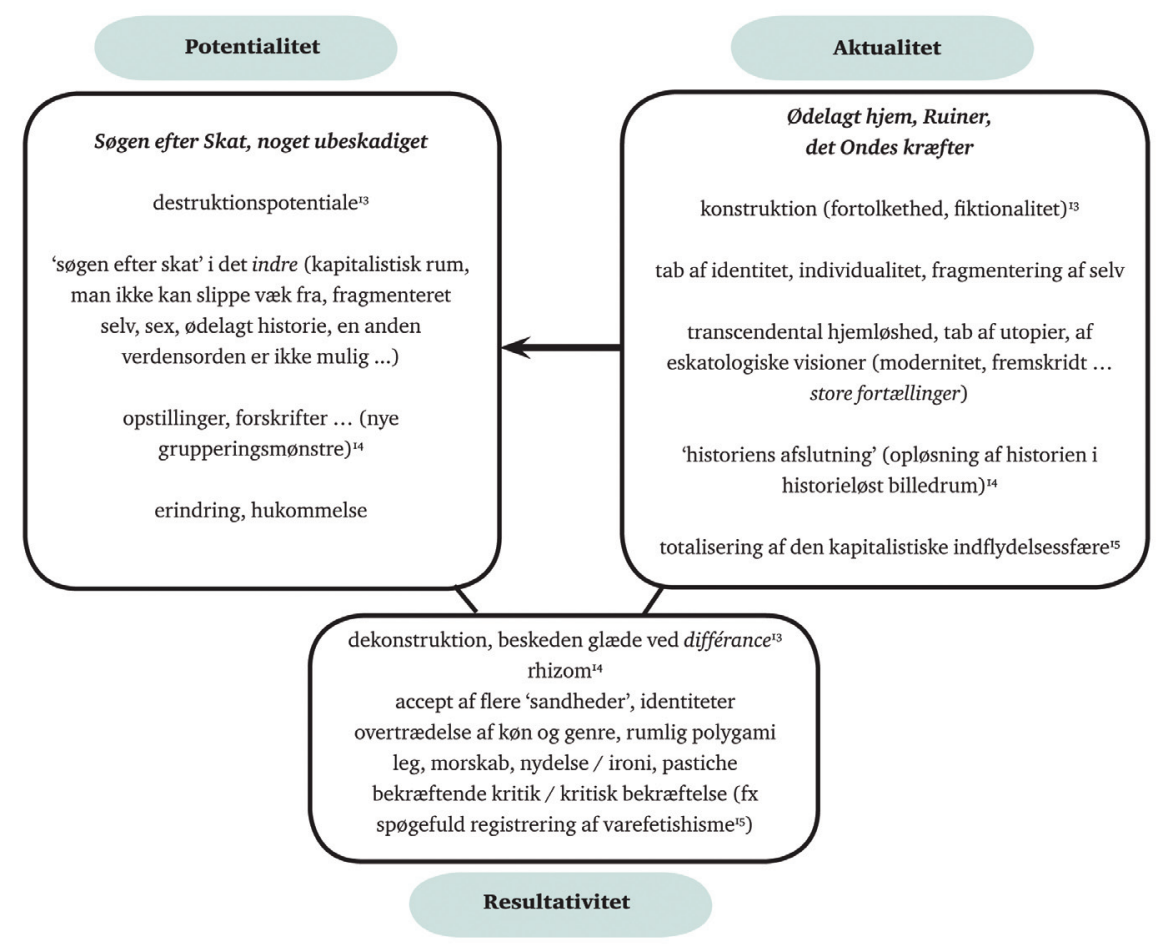

Figur 2: Postmodernistiske nøgleideer fordelt på komponenterne i Falks malisme.

For at illustrere den antagelse, at basisstrukturen på grund af globaliseringen også burde kunne anvendes på samtidig arabisk (og anden mellemøstlig) litteratur, har jeg udvalgt et af de motiver, der uden tvivl dukker op flest gange i litteraturen henimod slutningen af det 20. århundrede - tabet af individuel identitet, dvs. destruktionen af 'selvet'. Det giver sig selv, at dette tab let kan identificeres med det malistiske billede af det Ødelagte Hjem. Det sammenstilles bl.a. med det lige så hyppige motiv morskab, eller nydelse, der præger den arabiske litteratur i tiden efter 1980. Her, som i tysk og megen anden litteratur, kommer nydelse af heltens anstrengelser for at bjærge en Skat fra en form for Ruiner. Hvis vi koncentrerer os om billeder og repræsentationer af det Ødelagte Hjem, henholdsvis typerne Skat og Nydelse, dvs. om de metaforer og plotallegorier, forfatteren bruger for at gengive en vis erfaring eller holdning, vil vi få mulighed for at kigge lidt dybere i den psyko-emotionelle dimension, der kendetegner komplekset 'tab af identitet' samt de elementer, der opvejer den. 


\section{Individualiteten tabt - Helvede truer}

I nogle arabiske tekster fra et tidligt første stadie af malismen kan Aktualitetens malistiske kræfter imidlertid stadig opleves af forfatterne som noget, der er så stærkt og overvældende, at en Skat endnu ikke kan opdages overhovedet eller dens eksistens bedst på en eller anden måde opfattes ubevidst. Det er fx tilfældet i Jabrā Ibrāhīm Jabrās The Other Rooms (al-Ghuraf al-ukhrā, 1986), en roman, der er blevet beskrevet om en 'overbevisende parabel over den ensomhed og fortabthed, individet oplever i moderne samfund, og en nøjagtig gengivelse af hans lidelse. ${ }^{16}$ Som i de tyske tekster fra den tidlige malisme, Walter Falk havde analyseret, er der stadig absolut heller ingen nydelse eller lykkelig slutning her; vi har dog allerede et antal billeder af et Ødelagt Hjem, som vi kommer til at møde senere også i Opnået Nydelse-teksterne, hvor frygt og nogle gange panik vis-à-vis ødelæggelsens katastrofe afbalanceres af mere positive kræfter og tit endda mere optimisme. I Jabrās roman er disse forestillinger stadig fraværende. Den åbner med, at helten står alene om natten på en stor plads, som

46 lå der, tom, ensom og øde, glemt at Gud og mennesker. Det var, som var der i byen ikke et menneske tilbage, der stadig ville bevæge sig, kæmpe eller elske, som om en plage havde sænket sig over den og ikke havde skånet en eneste (Ghuraf, 7). ${ }^{17}$

Her udgøres ødelæggelsen af Hjemmet først og fremmest af dets mennesketomhed..$^{18}$ I denne situation optræder de første sataniske figurer i teksten: fx en mand iført en sort frakke, der når helt ned til hans ankler, eller en meget smuk kvinde, en satanisk fristerinde og forførerske eller en sirene, der opfordrer ham til at følge sig ind i en uhyggelig, stor bygning (hvis beskrivelse minder mig om det mareridtsagtige Mugamma'-kompleks på Cairos Tahrīr Plads, men selvfølgelig let kan været udformet med et sikkerhedshovedkvarter i et arabisk land, eller måske ligefrem det berygtede Ljubljanka, som forbillede). Inde i den bygning bliver han ført - det fremgår ikke klart, om det skyldes en hemmelig plan eller handler om rent held - fra et rum til det næste. Romanens labyrint-agtige topografi ligner de udgaver af Helvede, man møder i mange andre malistiske tekster. Adskillige djævelske personer dukker op iført altid skiftende masker og afholder helten fra at definere, eller huske, hvem han er. De påtvinger ham identiteter, som han forsøger at afslå, men han kan ikke stole på sin egen identitet, for jo dybere han bliver trukket ind i Labyrinten af Djævlene, desto mindre sikker er han på sit eget selv. ${ }^{19}$ Når han kigger i spejlet, ser han en anden person, med overskæg og grå tindinger (Ghuraf, 20), og når han leder i sin lomme efter id-kort, finder han ikke bare et enkelt, men en hel stak af den slags kort, alle udstedt med forskellige navne og stillinger (jf. Ghuraf, 84).

Ud over dette 'tab af identitet'-tema indeholder romanen endnu et element, der ses igen og igen i malistiske tekster: en tiltagende forvirring over, hvad der er virkelighed, og hvad der kun er fantasi, dvs. en udviskning af grænser mellem virkelighed og fiktion. Dette emne blev kort berørt så tidligt som i 1967 af Nagīb Maḥūz i hans skelsættende fortælling Under the Bus Shelter (Taht al-mizalla), en tekst skrevet un- 
der påvirkning af chokket over den tabte Seksdageskrig og de arabiske illusioners efterfølgende sammenbrud. En gruppe mennesker, der står i et læskur ved et busstoppested $\mathrm{i}$ ly for regnen, bliver vidner til totalt underlige begivenheder, der finder sted for øjnene af dem på gaden i regnen, og denne 'virkelighed' er så absurd, så obskøn, så grotesk og så brutal, at de ikke kan tro, at dette kan være virkeligt, men må tro, at det er optagelserne til en film. Mahfūz er imidlertid endnu ikke 'postmoderne' nok til at lade begivenhedernes ontologiske status være uafklaret: Trods det at verden er rystet, er der stadig en vis ontologisk sikkerhed. Det er ikke tilfældet i de malistiske tekster halvandet til to årtier senere. I en scene tæt på slutningen i Jabrās Ghuraf oplever helten et øjebliks lykke, fordi han begynder at huske detaljer fra fortiden og, sammen med disse fragmenter af sin personlige historie, tror, han er begyndt at få sin tabte identitet igen (Ghuraf, 87ff.). Blot nogle få øjeblikke senere går han imidlertid tilfældigvis forbi et bord, på hvilket der ligger en bog med titlen 'Alternativet', og da han åbner den, kan han her læse ord for ord, som en del af den trykte tekst, nøjagtig de tanker, han gik og funderede over for ganske få minutter siden! Ubeslutsomheden mellem en 'virkelig' eksistens og en eksistens, der er brygget sammen af en eller anden ukendt forfatter, dvs. usikkerheden over for en identitet selv $i$ dens ontologiske status, eller det, at den måske blot er en kopi af noget andet, virker meget frygtindgydede i Jabrās roman: Helten rammes af et voldsomt slag, han bliver næsten vanvittig, og kun meget langsomt begynder hans panik at lægge sig. Ikke desto mindre findes der faktisk en vej ud af forvirringen, og helten befinder sig til sidst uden for labyrinten. Han er imidlertid ikke specielt glad for det, og med rette - for det står på ingen måder klart, om hans flugt er 'virkelig' eller kun 'virtuelt virkelig'. Programmet for den følgende nat, som han får af folk, der venter ved udgangen, er nøjagtig det, han lige har været igennem den foregående nat. Fortid og fremtid smelter på den måde sammen, og det er ikke længere muligt at orientere sig, da selv Tiden er faret vild.

En tilsvarende "kafkask ${ }^{20}$ atmosfære bliver fremmanet et årti tidligere iṢun 'allāh Ibrāhīms The Committee (al-Lajna, 1981), en tekst om det politiske system i Egypten under den økonomiske 'liberalisering' (reelt primitiv kapitalisme), der fulgte i kølvandet på Anwar al-Sādāts infitāh-politik, dvs. 'åbning' over for Vesten, rettet mod udenlandske investorer. Romanen begynder med, at helten venter på at blive undersøgt af en grotesk komité, og selvom den stadig fremviser langt mindre ontologisk-eksistentiel forvrængning end Jabrās Ghuraf, er beskrivelsen af Komiteens hovedkvarter og karakteristikken af medlemmerne af Komiteen i al deres grovhed og diabolisme, meget tæt på det, man kan læse i Jabrās text..$^{2 \mathrm{I}}$

En tilsvarende pessimistisk tone dominerer næsten alle tidlige malistiske tekster. I nogle af dem er den forvrængede identitet endnu ikke nødvendigvis et væsentligt element i Aktualitets-laget (skønt identitetsproblemer sagtens allerede kan 'svæve over vandene'). I In Hanān al-Shaykhs Zahras historie (Hikāyat Zahra, 1980) spilles rollen som Djævelen for eksempel af en snigskytte under den libanesiske borgerkrig. Denne mand er ikke kun grusom, men udøver også en sær og alligevel uimodståeligt stærk tiltrækning på heltinden (således er han klart en af Fristerne/Sirenerne, vi allerede har mødt i adskillige andre tekster), og hans tiltrækning forårsager en udvikling i kvindens personlighed, der kan fortolkes som en udfordring af hendes 
identitet. I Gamāl al-Ghīṭānīs Epistle of Insights into the Destinies (Risālat al-bașā' ir $f_{\imath}$ 'l-mașā'ir, 1989) udgøres Aktualitetens Ødelagte Hjem af hele vor tids Egypten. Djævlene her optræder som pædofile arabere fra Golfen, som egyptiske entreprenører fra den ny infităh ('åben dør'-politik)-klasse, som skrupelløse kapitalistiske udbyttere osv. I de fleste af de mange enkeltstående historier, der fortælles i teksten, er identiteten også i spil. ${ }^{23}$ I et antal andre fortællinger bliver elementet det truende rum, som vi allerede har set i hovedkvarteret i Jabrās Other Rooms eller Șun'allāh Ibrāhīms Committee, den overvejende hovedmetafor, der på den måde svarer meget bogstaveligt til Falks beskrivelse af malistisk aktualitet som det 'Ødelagte Hus/ Hjem'. Det er fx tilfældet i'Abduh Gubayrs Moving the Heart (Tahrīk al-qalb, 1982), en roman endnu engang om Sadats Egypten, der her sammenlignes med en forfalden bygning, der 'huser', eller nærmere truer, de, som stadig bor i den. ${ }^{24}$

Det, der i Jabrās Other Rooms eller Șun'allāhs Committee stadig forbliver en anelse svævende - relationen mellem to vigtige tematiske fokuspunkter i vores tekster, 'tabet af en individuel identitet'i en labyrintagtig verden og den diabolske 'virkeligheds-fiktions'-forvirring, ${ }^{25}$ er en smule mere klart i andre værker. På en måde bygger de alle sammen på Mahfūz' Under the Bus Shelter (Taht al-mizalla, 1967), hvor 'virkeligheds-fiktions'-forvirringen allerede er knyttet sammen med sproget som et redskab til at forme 'virkelighederne', til at skabe nye forestillede verdener, et emne der kommer under kraftig behandling nogle få år efter, fx af Gamāl (eller også Jamāl) al-Ghīțānī i hans Zayni Barakat (al-Zìnn̄ Barakāt, 1974), forfatterens monumentale gøren regnskabet op med den totalitære nasserisme, forklædt som historisk roman om den sene mamlukiske periode i Egypten. Senere i de malistiske tekster bliver forbindelsen mellem sprog og magt tit udvidet til identitetsproblemet, der står centralt i perioden: Identiteter er ikke troværdige fakta, men ideologisk (og lingvistisk) opspind, der kun er til fordel for de, som har magten. Fiktion ses således som et magtredskab, der ved at vildlede folk til at tro på, lad os sige, den nationale identitets virkelighed, gør det muligt at herske over dem. ${ }^{26}$ Den fatale, men på en måde også yderst ironiske, konsekvens er, at ved at anlægge en sådan ideologisk fremstillet 'sand' identitet, som forsikrer dig om din individualitet vis-à-vis den Anden, taber du din sande identitet og bliver i realiteten af-individualiseret.

Den libanesiske forfatter Ilyās Khūrī (Elias Khoury) har allerede i 1977 grebet problemet med den tabte, eller i det mindste anfægtede, identitet som et resultat af magt-diskurser an fra en anden vinkel i sin roman - eller novellesamling, som nogle foretrækker at kalde den - The Little Mountain (al-Jabal al-șaghīr). Her trues identiteten, i form af 'sandheden' og den indre kohærens i en personlig historie, af kampen om det diskursive overherredømme blandt de rivaliserende styrker under den libanesiske borgerkrig. Temaet uddybes med stadigt skarpere kant af den samme forfatter et årti senere, lige midt i den malistiske periode, i The Journey of Little Gandhi (Rihlat Ghāndī al-șaghīr, 1989). Med den israelske invasion i Beirut i 1982 som bagtæppe genfortælles historien om 'Lille Gandhi', en skopudserdreng, en tilfældig forbipasserende, der bliver skudt ved en fejltagelse, mens 'begivenhederne' står på, fra flere forskellige perspektiver som noget, der dukker frem af hukommelsen hos nogle af de mennesker, der kendte den stakkels, uskyldige dreng. Under krigens betingelser, gør teksten det klart, tæller et menneske ikke, de bliver bare opløst, for- 
svinder, bliver ofre for rivaliserende historiske og politiske kræfter, ikke kun fysisk, men også som en del af historien, den historiske 'realitet'.

\section{Nydelse vundet - Nogle hyppige motiver}

Tekster som Jabrās Other Rooms eller Khūrīs Little Mountain og Journey of Little Gandhi følger tilsyneladende den samme vej, der går ud på at dekonstruere veletablerede kendsgerninger og tidligere accepterede identiteter ( $=$ de Hjem, der ses ødelagt i malismen), og det lader til, at de gør det for at åbne vejen for næste trin, en søgen efter en måde at håndtere 'Ruinerne', fragmenter af 'Huset' og, måske, opdagelse af noget, der har overlevet alle ødelæggelserne ubeskadiget. Og det er lige det, der sker i de 'Nydelse vundet'-tekster, jeg nu vil tage fat på, skønt den løsningen på identitsproblemet, som de tilbyder, er nok så overraskende: Ægte individualisme går ifølge dem ud på at acceptere din manglende individualisme, et fragmenteret selv sat sammen af mange forskellige identiteter. En historie i den tyrkiske Nobelprismodtager Orhan Pamuks berømte Den sorte bog (Kara Kitap, 1990), ${ }^{27}$ som ikke er en arabisk fortælling, men som jeg tillader mig at medtage i diskussionen her, fordi det er en af nøgleteksterne i den mellemøstlige litteraturs periode, kommer med et såre simpelt eksempel. Blandt mange andre 'eventyr' fortæller den historien om en ung prins, der $\varnothing$ nskede at være helt og aldeles sig selv. ${ }^{28}$ Han fors $\varnothing$ gte at skille sig af med alt det, der kunne øve en negativ indflydelse på ham og korrumpere hans individuelle selv, ved systematisk at udelukke al indflydelse udefra - lærere, bøger, møbler, alt - blot for at opdage, at der til sidst heller ikke var noget tilbage af ham selv! At søge efter en ren, ubesmittet individualitet, må vi konkludere, fører altså ikke til noget. At acceptere, at du er en sammensat skabning, vil derimod befri dig fra byrden med at skulle søge efter en fast defineret identitet og binde dig til et ideologisk præfabrikeret selvs stramme og næsten kvælende korset. Med den frihed, du vinder, hvis du accepterer, at du er en sammensat skabning, vil du også vinde nydelse, fordi du først nu vil blive i stand til at leve fuldt og helt med alle det nye livs fascinerende aspekter og ikke længere bliver nødt til at undertrykke nogen af de elementer, der udgør dit selv, uanset hvorfra de måtte stamme.

Denne løsning har selvfølgelig, sammen med dens afstigmatiserende og aftabuiserende virkninger, både politiske, psykologiske, sociokulturelle og litterære dimensioner, som alle behandles, hver for sig eller i forskellige kombinationer, i 'Nydelse Vundet'-teksterne. Samtlige af de sidstnævnte begynder med skræmmende billeder af en tabt identitet, der ligger meget tæt på dem, vi finder i Jabrās Ghuraf eller andre tekster fra den tidlige malisme generelt set. At indse, at en individuel identitets og en troværdig virkeligheds varme og trygge Hjem er blevet ødelagt (aktualitet), kan i første omgang opleves som lammende, men snart drager heltene af sted for at gennems $\emptyset$ ge ruinerne efter dette Hjem i deres søgen efter noget, der er forblevet uskadt (potentialitet). Til denne søgen bliver en rejses plot-mønster hyppigt taget i brug, og meget tit er det en rejse, der går igennem en slags ørken, via en labyrint eller et helvede - i ordenes metaforiske betydning, naturligvis; i de konkrete tekster kan disse ørkener, labyrinter eller helveder være en by, en region, en bygning, tit steder eller rum, der er 'ødelagt af moderniteten'. ${ }^{29}$ I City of Saffron (Turābuhā za'farān, 1985) ${ }^{30}$ 
lader den egyptiske forfatter Edward al-Kharrāt for eksempel sin hovedperson vandre gennem sin hjemby Alexandria og på en og samme tid gennem sin egen (hhv. fortællerens) fortid, hans helt Mikhā'īl (Michael) ser sig selv stå ansigt til ansigt med ruinerne af sit eget liv, men også med den omgivende verdens aktuelle tilstand; han føler sig truet af den menneskelige eksistens' generelle flygtighed og begrænsethed (jf. Turābuhā, 2. udg., 125) og forestiller sig, at han balancerer på en 'skrøbelig, farlig kant, mellem væren og intethed' (ibid., 126), hvor han ser 'dødens kyster' (shāți' almawt, ibid.) for sig i syner. Heltinden i Tahar Ben Jellouns La nuit sacrée (Den hellige nat, 1987) ${ }^{3 \mathrm{r}}$ befinder sig i en tilsvarende situation, idet hendes far har tvunget hende ind i en maskulin identitets 'helvede' og opdraget hende som sønnen Ahmed, han kunne være stolt af. Efter faderens død - den patriarkalske hersker, der regerede ved hjælp af en ideologi (= en slags fiktion), men naturligvis også en af de mange Sataner, der optræder i denne fortælling (se herunder) - ændrer Ahmed sit navn til Zahra og begiver sig på en rejse fuld af eventyr på jagt efter sin identitet.

Et antal forfattere sporer tabet af identiteten og individualiteten tilbage til den destruktive indflydelse fra udlændinge og/eller deres samarbejdspartneres aktiviteter i deres lande. Șun 'allāh Ibrāhīm kaster sig for eksempel i sine værker, som mange andre, ud i rejser gennem massernes hverdagskultur, som, i Egypten såvel som i andre mellemøstlige lande, er formet og kontrolleret i enhver henseende af et magtfuldt politisk-økonomisk oligarki, der har monopoliseret produktion og magt; jf. Șun 'allāh Ibrāhīms ovenfor omtalte The Committee og Zaat (Dhāt, 1992). I Libanon var det borgerkrige, der ødelagde Hjemmet, og sammen med rædselsvækkende erindringer om 'begivenhederne' er mange andre erindringer fra fortiden, dvs. historien, blevet fortrængt efter krigens afslutning. Det er grunden til, at fortælleren i Ilyās Khūrīs Journey of Little Gandhi (Rihlat Ghāndī al-șaghīr, 1989) har visse problemer med at få oplysninger om, hvem Lille Gandhi var. I lighed med historien om den lille skopudserdrengs liv ligger hans identitet 'i ruiner' og endnu engang er romanen - der i bund og grund repræsenterer et fors $\varnothing g$ på at rekonstruere den tabte identitet - organiseret som en 'rejse', denne gang en rejse fra den ene informant til den anden. Opholdene på denne rejse er de historier, som fortælleren får fortalt af de folk, han møder, og dette mønster går igen i mange andre tekster, fx Gamāl al-Ghīṭānīs gennemgang af livet i Sadats Egypten, The Epistle of Insight into the Destinies (Risālat al-bașā' ir fī 'l-mașā' ir, 1989). I en af al-Ghīțānīs tidligere romaner, Khițaț al-Ghīțānī (al-Ghītān̄î̀'s Districts, 1981) er det ikke fortællinger, der fungerer som ophold på en rejse; i stedet lægges identitetens puslespil ved at besøge en masse steder og rejse igennem mange distrikter, så rejsen bliver en slags historisk-topografisk gennemgang (hvad man muligvis allerede har regnet ud ud fra bogens titel ${ }^{32}$ ).

I alle disse tekster optræder stadig mange djævelske figurer og/eller kræfter, der minder om dem, vi ser i tidlige malistiske tekster som Jabrās Ghuraf. De kan tage mytologisk-ladede former eller tilhøre Sirene/Frister/Forfører-typen, vi allerede har mødt herover. I al-Kharrāț City of Saffron er det Død og Tid, der spiller rollen som diábolos, ${ }^{33}$ der truer alt og alle, ikke kun med fysisk udryddelse, men også med at gå i glemmebogen, dvs. med udslettelse fra andres erindring. I Ben Jellouns L'enfant de sable (Sandbarnet, 1985) ${ }^{34}$ og dens efterfølger, La nuit sacrée, er Djævelen en almægtigfader. 
Når de står ansigt til ansigt med ruinerne af det Ødelagte Hjem eller på deres rejser udforsker ruinernes og labyrinternes dybde, indser heltene i vores tekster imidlertid ikke kun omfanget af de skader og ødelæggelser, de skal håndtere; de opdager også, som vi allerede har været inde på, visse 'skatte', der altid har været der, men som de knapt nok har fået øje på, ting som Satanerne har forsøgt at skjule hele tiden, eller som har ligget begravet et sted dybt nede i tidligere tider. Helte, der har tabt deres individualitet vinder nydelse, hvis det lykkes for dem at bjærge Skattene, og det lykkes faktisk for dem, lige så snart de formår at overvinde individualitetens, originalitetens eller autencitetens 'nødvendighed', som fra Romantikken og frem havde begrænset mulighederne for alle, der ønskede at være helt og aldeles 'sig selv', dvs. så individualistiske som muligt. En forfatter skulle fx finde sin helt egen, individuelle stil, og derfor kom han til at opfatte den litterære arv som en 'æstetisk Index librorum prohibitorum'; ${ }^{35}$ han var på en eller anden måde nødt til at skille sig ud fra den, forbedre eller overgå den..$^{36}$ Det samme gør sig gældende for nationalistiske ideologier, som også blev formuleret i romantikkens perioder. De tvang også en nation til at finde en særlig identitet, et individuelt selv med sine egne rødder, sine egne skikke, sin egen 'nationale personlighed', der på alle måder skilte sig ud fra de andres. Også her blev visse aspekter af arven udelukket og stigmatiseret.

Når først du har befriet dig selv fra de ideologiske=fiktive begrænsninger, åbner horisonten sig imidlertid op for ubegrænsede muligheder. Alverdens Skatte venter på at blive bjærget og efterfølgende nydt. I vore tekster (såvel som i samtidig ikkeorientalsk litteratur) kan det være ren og skær seksuel nydelse eller i det mindste nydelsen ved at tale frit om seksuelle spørgsmål - det er grunden til, at litteraturen er endt med at lægge visse træk frem, som en konservativ læserkreds ville finde uanstændige, for ikke at sige direkte pornografiske. ${ }^{37}$ Det kan være nydelsen ved selve det at fortælle, naivt, enkelt og totalt naturligt, fri for alle 'modernistiske' begrænsninger - det er derfor mange tekster bliver fortalt, som var det en traditionel historiefortæller, der sad på en markedsplads eller en café. ${ }^{38}$ I nogle tilfælde er det imidlertid lige det modsatte af den pseudo-naive fortælling: en tendens i retning af det Jean Fontaine kalder en écriture hermétique. ${ }^{39}$ Skatten ligger måske også gemt i sproget - derfor strækker det lingvistiske spektrum sig fra sprogets ældre former ${ }^{40}$ over undergrunds-slang ${ }^{41}$ til en sprød poetisk tone. ${ }^{42}$ Meget tit udgøres Skatten også af fortiden og/eller historien. Det ses bl.a. i en stigning i antallet af historiske romaner ${ }^{43}$ samt tekster, der udspiller sig i en nostalgisk atmosfære, ${ }^{44}$ og memoirer ${ }^{45}$ Det ses også i den måde, færdigheder, der i tidligere tider mentes at være kilde til styrke eller velstand, bliver manet frem igen og igen. Og så er der også mysticismens Skatte, ${ }^{46}$ en kærlighed til det mystiske og det eksotiske, men også til hverdagskultur, ${ }^{47}$ til marginale sub-kulturer, ${ }^{48}$ populære skikke, til gennemlevet bikulturalisme $e^{49}$ og så videre.

Den nyligt vundne nydelse kommer i de fleste tekster til udtryk som en fri leg, der ignorerer alle 'kunstens regler' eller grænser. ${ }^{50}$ Den nye identitet er ikke skarpt trukket op og begrænset, men er via sin åbenhed, irregularitet og klart manglende originalitet blevet ekstremt rig, farverig og livlig. Engang imellem virker det også som om det afspejler sig i teksternes længde. På grund af den nydelse, det helt klart er for deres forfattere at dvæle ved selv den mindste detalje og deres løsslupne nar- 
rative energi, er mange bøger meget tykkere end tidligere eksperimenterende tekster. ${ }^{5 \mathrm{I}}$ Men mange af dem ønsker samtidig heller ikke at blive læst fra ende til anden. Også læseren har lov til at tage let på sine læseopgaver, når det gælder disse 'tykke bind'. Mange af dem kan åbnes på samme måde, som vi går ind på en hjemmeside på World Wide Web og begynder at surfe frit, idet vi springer fra link til link; de, der mener, at de på en eller anden måde burde mestre webbet og skaffe sig et samlet overblik, er tabt, mens de, der ikke stræber efter at mestre det, kan få stor nydelse af det. ${ }^{52}$

Figur 3 forsøger at opsummere resultaterne af vores læsning af arabiske og nordafrikanske frankofone romaner fra tiden efter 1980. En af de vigtigste konklusioner, jeg selv drager på basis af disse resultater, særligt den modsigelsesfrie anvendelighed af Falks system på mellemøstlig litteratur, er, at den måde, livet opfattes i disse regioner hen imod slutningen af det 20 . og begyndelsen af det 21 . århundrede, ikke adskiller sig fundamentalt fra den måde, vi oplever det i Vesten. Der er et globalt diskursivt fællesskab med ens syn på livet på begge sider, snarere end et 'civilisationernes sammenstød'.

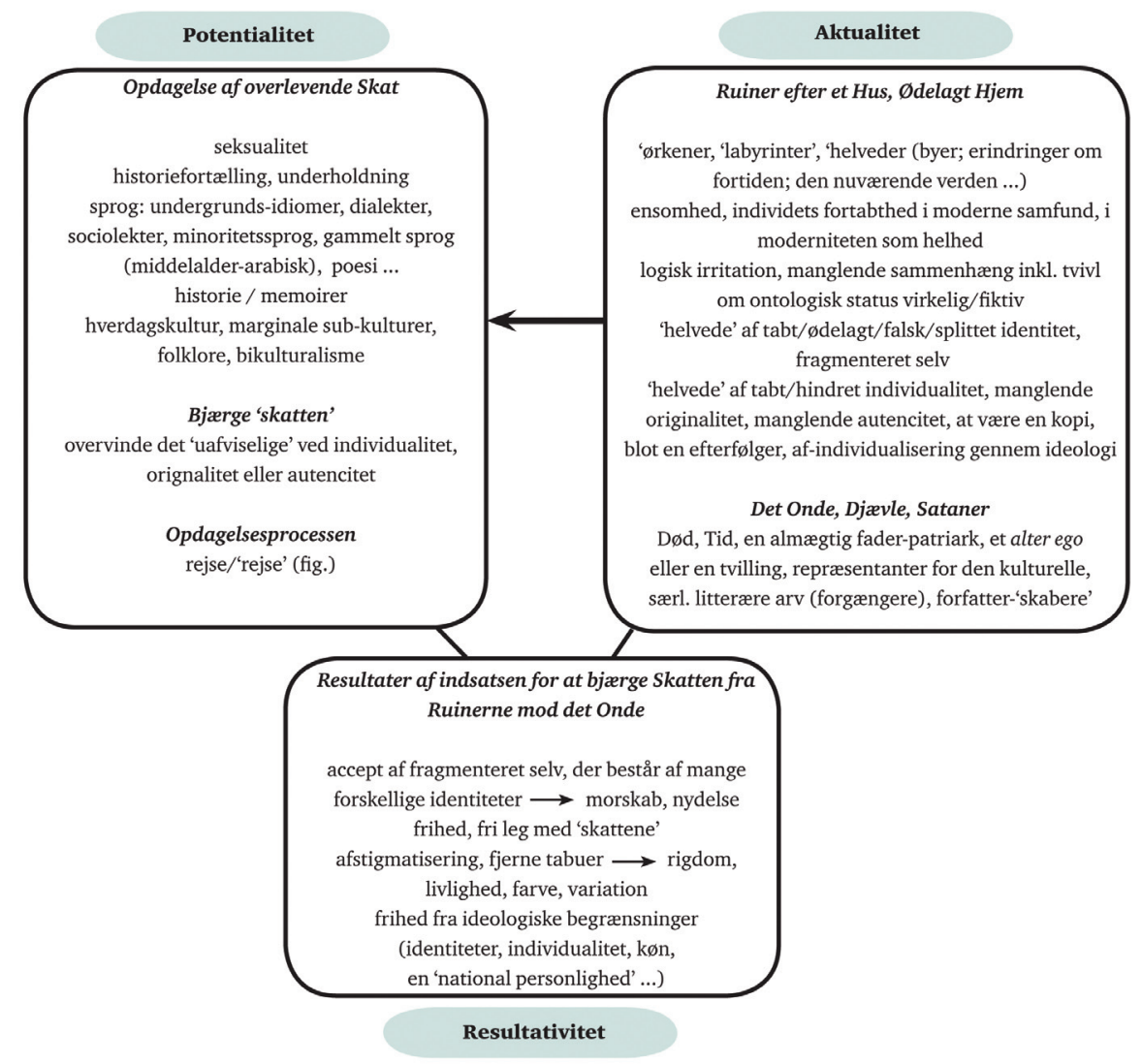

Figur 3: Fordeling af tilbagevendende temaer fra Maghreb og Mashriq på den malistiske PAR-strukturs kategorier. 


\section{Noter}

I En mere detaljeret udgave (der også dækker tyrkisk samtidslitteratur) blev bragt i Journal of Arabic and Islamic Studies 7 (2007) [udg. feb. 2008], pp. 25-49, under overskriften 'Individuality Lost, Fun Gained. Some Recurrent Motifs in Late Twentieth-Century Arabic and Turkish Novels'. Se tidlig version her: www.uib.no/jais/v007/GuthPP.pdf.

2 Andreas Pflitsch, A. Neuwirth, B. Winckler (red.), Mü: edition \& kritik.

3 Den vil helt sikkert få stadigt større opmærksomhed, når den engelske udgave, Arabic Literature: Postmodern Perspectives, udkommer til næste år (planlagt til maj 2010) hos Saqi Books, London.

4 Workshoppen var en del af 8th Conference of the European Association for Modern Arabic Literature (EURAMAL), der blev afholdt på Universitetet i Uppsala, 11.-14. juni 2008. Konferencen havde overskriften From New Values to New Aesthetics: Turning-Points in Arabic Literature Since the 1960s. Referat er under udarbejdelse.

5 Denne proces er beskrevet i detaljer (for så vidt angår den tyrkiske og den arabiske roman) i min Brückenschläge: Eine integrierte 'turkoarabische' Romangeschichte (Mitte 19. bis Mitte 20. Jhdt.) og i en opsummerende udgave i min 'The Simultaneity of the Non-Simultaneous: The Global Dimensions of Middle Eastern Literature (esp. in the 19th Century)'.

6 Jf. Walter Falk: Parallele Ägypten.

7 Min Falk'iske tilgangs holistiske og systematiske karakter vil også være et træk, der adskiller den fra studier af postmodernismen i mellemøstlig litteratur, hvor værdifulde de end måtte være, som ovennævnte Arabische Literatur, postmodern (jf. note 2).

8 Jf. Walter Falk: Das Sinnsystem der gegenwärtigen Periode: Präzisierun $\neg$ gen der bisherigen Deutung (Zusammenfassung).

9 For en gennemgang af den underliggende teori om den tredelte 'meningsstruktur' og den tilhørende metode til litterær analyse, se Walter Falk Handbuch der literarwissenschaftlichen Komponentenanalyse. En kort introduktion til de grundlæggende begreber inden for 'komponentiel analyse' kan læses på MKE's website: www.walter-falk.de/einfuhrung.htm.

Io Jf. særligt Walter Falk: Die Ordnung in der Geschichte. Kortfattet resumé, fx i Walter Falk: Václav Havels Briefe aus dem Gefängnis, p. $240 \mathrm{ff}$.

II Aktualitet kan kun være lig med tese i perioder, som kan tilskrives det, Falk kalder 'prioritet' over Potentialitet, dvs. hvor Potentialitet manifesterer sig som et svar på Aktualitetens tilsynekomst. Der er perioder i hvilke den stimulerende impuls udgår fra Potentialiteten, og Aktualiteten er den sekundære komponent, der kommer til at føles som en udelukkende antitetisk kraft, der blokerer, som en reaktion på Potentialitetens tilsynekomst, der tidligere har ladet sig føle. For yderligere detaljer se Falk: Handbuch, pp. 140-41 og 183. Aktualiteten, ikke Potentialitetens 'prioritet', i den periode, der anskues her (1980 og frem) er også en begrundelse for at benævne den efter hoveddrivkraften i dens Aktualitet, det 'Onde'. I diagrammet, er 'prioritets'-relationen udtrykt ved en pil (læs: det Ødelagte Hus går forud for opdagelsen af Skatten, eller: opdagelsen af en Skat kommer som et svar på den lidelse under de aktuelle omstændigheder, der opleves, som tabet af et Hjem osv.).

I2 I et indlæg ved MKE-gruppens årsmøde i 1997 anbefalede Falk, at man erstattede nogle af disse termer med nogle mere generelle, der ville betegne et højere abstraktionsniveau. Da jeg fandt disse nye termer ('das Urböse', 'Blockiertheit der Neuerung', 'Geschwächtheit des Bergenden') næsten uoversættelige, besluttede jeg at holde mig til den gamle terminologi, også fordi det metaforiske billedsprog er mere levende og ekspressivt. 
I3 De tre termer 'konstruktion,' 'destruktion' og 'dekonstruktion' henviser naturligvis til dekonstruktionistisk teori. Deres fordeling på Aktualitet, Potentialitet og Resultativitet gør det klart, at destruktionsprocessen i dekonstruktionen ses som et potentiale, der er motiveret af virkelighedens nuværende illusoriske, opdigtede karakter; det der kan opnås efter destruktionen af det tidligere trygge 'hjem', af en uspoleret tro på virkeligheden 'som den er', er resultater af en dekonstruktion, som er bevidst om sin begrænsede validitet.

I4 Terminologien her henviser til Hans Ulrich Gumbrechts skelsættende studie In 1926, som er tænkt som et forsøg på at skrive historie til trods for de store fortællingers sammenbrud og den såkaldte 'historiens afslutning'. Endnu en gang motiverer sammenbruddet af illusionen til muligheden for at henvise til fortiden 'sådan som den virkelig var' (aktualitet) historikere som Gumbrecht til at begynde igen, meget beskedent nede fra, og 'grave i ruinerne'. Det der synes at have overlevet ubeskadiget - muligheden for at omgruppere et stort og varieret historisk materiale i nogle grundlæggende kategorier (som Gumbrecht kalder 'opstillinger', 'forskifter' og 'brudte forskrifter') - kan karakteriseres som en skat, der gør det muligt for historikeren at nærme sig historien trods 'historiens afslutning'. I Gumbrichts tilfælde opfører den nye form for historie sig som jordstængler (resultativitet) og ender som en bog, der ikke skal læses fra ende til anden, men består af leksikonagtige artikler, fra hvilke læseren via krydsreferencer ledes videre til andre artikler.

I5 Jf. Fredric Jameson, Postmodernism, Or, The Cultural Logic of Late Capitalism, 1992.

I6 Frit efter bagsideteksten til den tyske oversættelse af al-Ghuraf al-ukhrā (se 'Tekster' til sidst i denne artikel). Jf. også Hartmut Fähndrich, 'Nachwort', ibid., p. 135.

I7 Oversat til dansk efter Stephan Guths engelske oversættelse. O.a.

I8 Her og i det følgende sætter jeg de træk i kursiv, der er karakteristiske for en af de malistiske komponenter.

I9 Jf. Fähndrich, 'Nachwort', pp. 134-35.

20 Også Jabrās Ghuraf viser naturligvis stærke intertekstuelle referencer til Kafka, særligt til sidstnævntes Processen .

2I For yderligere referencer, jf. kapitlet om al-Lajna i min Zeugen einer Endzeit, pp. 114-149.

22 For en detaljeret analyse af denne tekst, jf. min 'Jamāl al-Ghīṭānī og The Epistle of Insights into the Destinies (1989)'.

23 Jf. min Zeugen einer Endzeit, pp. 150-99 og passim på pp. 226-94.

24 For en detaljeret analyse, jf. min Zeugen einer Endzeit, pp. 82-113. 'Huset' synes at være en passende metafor selv senere i tekster, det ville være svært fortsat at beskrive som 'malistiske' eller, med konventionel terminologi, som 'postmoderne', fx 'Alā' al-Aswānīs Yacoubians hus ('Imārat Ya 'qūbiyān, 2002; [dk. udg. overs. fra engelsk af Ingeborg Christensen, 2007]), hvor et 'hus' optræder allerede i romanens titel.

25 Bemærk, at ordene 'djævel' og 'djævelsk' går tilbage til det græske verbum diabállein 'at kaste (-ballein) fra hinanden (dia-)', en diábolos er således 'en, der vender ting på hovedet, forvirrer, snyder, bagtaler'.

26 Ideen om den 'opdigtede virkelighed' er også central allerede i Șun 'allāhs al-Lajna (1981). Her er helten imidlertid stadig sikker på sin egen identitet og forsøger blot at afsløre magthavernes falske identitet. Hvis man alene bedømmer romanen ud fra helten, er der nok ikke grundlag for at betragte al-Lajna som en 'tabt individualitet'-tekst. Jf. imidlertid, hvad vi kommer ind på herunder, når vi atter diskuterer temaet 'falsk verden' og 'forfalsket identitet.

27 For en sammenligning af Den sorte bog med Șun 'allāh Ibrāhīms The Committee, jf. min A World Full of Secrets: The Hero as Detective in Two Novels from Egypt and Turkey. 
28 Pamuk, Kara Kitap, kap. 16 ('Şehzadenin Hikâyesi’, pp. 386-404).

29 Kirchner, '»Das Schwarze Buch«', p. 50.

30 For studier af denne roman, jf. især Magda al-Nowaihi, 'Memory and Imagination in Edwar alKharrat's Turābuhā za 'farān,' og Andreas Pflitsch, 'Narration against Transitoriness and Temporality: Mythical Time Structure in Idwār al-Kharrāṭ's Works'.

3I Jf., også for yderligere referencer, Kindlers Neues Literatur Lexikon, 2: pp. 503-4, opslag under 'Ben Jelloun'.

32 Khițat al-Ghīṭān̄ hentyder til den berømte Khițaț by 'Alī Mubārak (1823-93) som til gengæld havde 'til hensigt at være et moderne modstykke til den mellemøstlige historiker al-Maknīzīs Khițaṭ' (Encyclopedia of Islam, 2. udg., opslag under “Alī Pāshā Mubārak' [K. Vollers]).

33 Jf. supra, note 25.

34 Jf., fx. Kindlers Neues Literatur Lexikon, opslag under 'Ben Jelloun', 2: pp. 502-3.

35 Manfred Fuhrmann: Der europäische Bildungskanon des bürgerlichen Zeitalters (Frankfurt: Insel, 1999), citeret in: Lesart 4 (1999): p. 3ff. ('Literaturkanon: Manfred Fuhrmann zur Geschichte des bürgerlichen Bildungskanons'), her p. 79.

36 Jf., fx Thomas Anz, 'Vorschläge zur Grundlegung einer Soziologie literarischer Normen', pp. 128-44, her p. 129; Douwe W. Fokkema, 'The Canon as an Instrument for Problem Solving'. Se også opslaget 'Originalität' in Metzler Lexikon Literatur und Kulturtheorie, pp. 408-9.

37 Jf. fx. mit studie 'The Function of Sexual Passages in some Egyptian Novels of the 1980s'. I de fleste tilfælde er det ikke hele teksten, men nogle få passager, der tjener dette formål, jf. fx M. Shukrīs For Bread Alone (al-Khubz al-hāfĭ, [1973] 1982) og The Time of Errors (Zaman al-akhțā', 1992), H. al-Shaykhs Story of Zahra (Hikāyat Zahra, 1980), T. Ben Jellouns La nuit sacrée (1987). Denne tendens synes at fortsætte indtil for ganske nylig med tekster, der ikke længere fremviser den narratologiske kompleksitet, der kendetegnde de malistiske tekster, men stadig betragter brud på seksuelle tabuer som en for dem væsentlig opgave. Den mest prominente af denne type tekster er formodentlig den egyptiske tandlæge 'Alā' al-Aswānīs Yacoubians hus ('Imārat Ya'qūbiyān, 2002; scener med homoseksuel kærlighed, arbejdsgiveres åbne diskussioner om sexchikane af deres unge kvindelige ansatte, erotiske eventyr med prostituerede, kærlighed og sex mellem en aldrende skørtejæger og en fattig, ung pige osv.), Aḥ̄ām Mustaghānimīds Memories in the Flesh (Dhākirat al-jasad, 1993) og Rajā' 'Abdallāh al-Ṣāni 's (Rajaa Al Saneas) The Girls of Riyadh (Banāt al-Riyād, 2005; efter vestlig smag synes denne tekst nok harmløs, men set i en saudisk kontekst må forfatterens brud på seksuelle tabuer betragtes som ret så vovede).

38 Jf. fx Hasan Dā’ūids The House of Mathilde (Bināyat Mātìld, 1983; overs. 1999), al-Ghīṭānīs Epistle of Insights into the Destinies (Risālat al-bașā'ir fi 'l-mașā'ir, 1989) eller Ben Jellouns L'enfant de sable og La nuit sacrée - for nu kun at nævne fire ud af et meget større antal. Den samme tendens rammer også plet i Vesten, hvor arabiske forfattere, der var næsten ukendte i deres hjemlande, blev fejret som store arabiske forfattere uden for den arabiske verden, efter at de var begyndt at 're-orientalisere' deres image ved at optræde som 'traditionelle arabiske historiefortællere'; det bedste eksempel på dette i de tysktalende lande er formodentlig Rafik Schami (dvs. Rafīq Shāmī).

39 Jean Fontaine: 'Du neuf dans le roman égyptien' in IBLA 6, no. 181 (1998): pp. 27-47, her p. $44 \mathrm{ff}$.

40 Vi har allerede nævnt Gamāl al-Ghīțānīs lån fra middelalderlige arabiske forfattere i forhold til hans Khițaț (jf. herover, note 32). Men der er mange andre tekster af den samme forfatter, som er stærkt inspirerede af den klassiske litterære arv, den vigtigste er endnu engang (den stadig 
præ-malistiske) Zayni Barakat.

4I Jf. sproget i Muhammad Shukrīs For Bread Alone (1973/1982) og den generelt set tiltagende litterære produktion på arabiske dialekter.

42 Det er for eksempel tilfældet med al-Kharrāṭ og også med hele qișșa-qașìda ('fortælle-digt' eller 'digt-fortælling')-bevægelsen (jf. Lale Behzadi: Die qișṣa-qașīda: Übersetzung und Untersuchung ausgewählter Kurzprosa der Sammlungen Madā'inu l-bad' und Ġawāyātu z-zill von Nāșir alHalawān̄i, Hildesheim; Zurich [etc.]: Georg Olms, 1996).

43 I Nordafrika kombinerer Assia Djebar, der selv er historiker, sin personlige historie med udforskning af si land, Algeriets, historie i L'amour, la fantasia (1985 [dk. udg. Kærligheden, Krigen oversat af Nina Gross (København, 2008)]); i det arabiske østen er det atter måske al-Ghīṭānīs al-

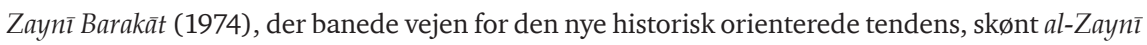
endnu ikke kan betragtes som et malistisk dokument.

44 Hasan Dā'ūds The House of Mathilde (1983), et antal episoder i al-Ghīțānīs Epistle of Insights (1989) eller al-Kharrāțs City of Saffron (Turābuhā za'farān, 1985) er gode eksempler på en længsel, der ikke alene bestemmer, hvad der fortælles, men også hvordan det fortælles, dvs. længslen har ikke kun indflydelse på indholdet, men også på skrivestilen. For al-Ghīțānīs Epistle jf. min artikel, Guth 2009 (se bibliografi).

45 Jf. blandt mange andre M. Shukrīs For Bread Alone og Time of Errors, al-Kharrāțs City of Saffron eller de autobiografiske dele/lag of A. Djebars L'amour, la fantasia.

46 Al-Ghītānīs The Book of Revelations (Kitāb al-tajalliyāt, 3 vols.: 1983, 1985, 1986) er et fint eksempel; jf. Rotraud Wielandt, 'Mystische Tradition und zeitgenössische Wirklichkeitserfahrung in Ğamāl al-Gīịtānīs Kitāb at-tağalliyāt', Asiatische Studien/Etudes Asiatiques 50 (1996): pp. 491523 samt 'Mystical and Mythical Journeys in Two Novels by Jamāl al-Ghīțānī', in A. Neuwirth et al., red., Myths, Historical Archetypes and Symbolic Figures, pp. 467-80.

47 Efter at have knyttet de forhindringer, den almindelige egypter står over for til hverdag, sammen med det politiske system i Sadat-æraen i The Committee, fokuserer Șun ‘allāh Ibrāhīms Zaat (Dhät, 1992) endda i langt højere grad på hverdagslivets banaliteter og besværligheder i den 'sen-kapitalistiske' forbrugerkultur i Mubaraks Egypten.

48 Jf. igen fx Shukrīs For Bread Alone og The Time of Errors. En forfatter, der især er kendt for at skrive om de marginaliseredes kulturer, er Yūsuf al-Qa 'īd (ikke Qu'ayyid, som nogle fejlagtigt gengiver hans navn). Hans monumentale trilogi, The Complaints of the Eloquent Egyptian (Shakāwā al-mișrī al-fașīh, 3 vols., 1981-85), diskuterer situatione for den store befolkningsgruppe i Cairo, der, fordi de ikke er i stand til at betale for bedre boliger, ser sig nødsaget til at bo på kirkegårde i den østlige del af den egyptiske hovedstad. Det samme miljø bliver behandlet af Jamīl 'Ațiyya Ibrāhīm i hans Descent to the Sea (al-Nuzūl ilā 'l-bahr, 1986).

49 Jf. det litterære output fra tyrkiske forfattere bosat i Tyskland, nordafrikanere bosat i Frankrig osv., arabere fra Mashriq i London eller USA. En af de romaner af denne type, jeg syntes bedst om, er Le thé au harem d'Archi Ahmed (Tea in the Harem, 1983) af Mehdi Charef.

50 Et antal tekster afspejler også eksplicit dette 'angreb' på konventionelle forventninger. Yūsuf al-Qa '̄ids Complaints of the Eloquent Egyptian (se note 48) har fx en lang indledning, der på en eller anden måde giver efter, omend i form af beklagelse, for reflektioner over det (u)passende vis-à-vis problemer, der trænger sig på, som sult og kampen for at overleve, lærde diskussioner om 'forfatterens død' eller postmoderne, narrative teknikker.

5I Jf. fx al-Ghīṭānīs Districts (se note 32) og hans Revelations-trilogi (!) (se note 46), Yūsuf al-Qa '̄îds Complaints (se note 48 og 50), endnu engang en tyk trilogi, eller Elias Khourys Gate of the Sun 
(Bāb al-shams, 1998), hans monumentale historie om de palæstinensiske flygtninge i Libanon, der ligesom hans tidligere romaner også behandler problematikken med at gendigte en rekonstruktion af den historiske 'sandhed' ved hjælp af historiefortælling.

52 I denne sammenhæng passer det, Priska Furrer (i sin 'Literatur und Hypertext: Nicht-Linearität im Kara Kitap des türkischen Autors Orhan Pamuk,' Studia Iranica, Mesopotamica et Anatolica 1 (1994): pp. 167-77) siger om det 'non-lineære' ved Pamuks Den sorte bog, også på en hel del arabiske tekster, særligt de tekster, der er arrangeret som 'samlinger' af kun løst forbundne episoder, som fx al-Ghīțānīs Epistle of Insights (se note 44), Khourys Little Gandhi (se p. 9) eller al-Kharrāț City of Saffron (se note 30).

53 Når mere end en udgave af originalen er nævnt, er det den seneste udgave, jeg henviser til i citater.

\section{Litteratur}

\section{TEKSTER ${ }^{53}$}

Al Sanea (eller Alsanea), Rajaa: se Șāni', Rajā’ 'Abd Allāh al- .

al-Aswānī, 'Alā'. 'Imārat Ya 'qūbiyān. Cairo: Dār Mīrīt, 2002 [and later editions]. Eng.overs. The Yacoubian Building (Overs. Humphrey Davies). New York: HarperCollins, 2006; Dk. overs. Yacoubians hus (Overs. Ingeborg Christensen). København, 2007.

Ben Jelloun, TaTehar. L'enfant de sable. Paris: Éd. du Seuil, 1985. Eng. overs. The Sand Child (Overs. Alan Sheridan). San Diego: Harcourt Brace Jovanovich, 1987, and Baltimore: John Hopkins UP, 2000; Dk. overs. Sandbarnet (overs. Lisbet Krogager). København, 1988.

Ben Jelloun, TaTehar. La nuit sacrée. Paris: Éd. du Seuil, 1987. Eng. overs. The Sacred Night (Alan Sheridan). San Diego: Harcourt Brace Jovanovich, 1989, and Baltimore: John Hopkins UP, 2000; Dk. overs.: Den hellige nat. (Overs. Lisbet Krogager) København, 1988.

Charef, Mehdi. Le thé au harem d'Archi Ahmed. Paris: Mercure de France, 1983. Eng. overs. Ed Emery, Tea in the Harem (London: Serpent's Tail, 1989).

Dā'ūu, Hasan. Bināyat Mātīld. Beirut 1983. Eng. overs. Peter Theroux, The House of Mathilde / Hassan Daoud (London: Granta Books, 1999).

Djebar, Assia. L'amour, la fantasia. [Paris]: J. C. Lattès, 1985. Eng. overs Fantasia: An Algerian Cavalcade (overs. Dorothy S. Blair) London: Heinemann, 1993; Dk. overs: Kærligheden, krigen, (Overs Nina Gross) København, 2008.

al-Ghīṭānī, Gamāl. Khițaț al-Ghīṭānī. Beirut: Dār al-Masīra, 1981.

al-Ghīṭānī, Gamāl. Kitāb al-tajalliyāt. Vol. 1, Cairo: Dār al-Mustaqbal al-'Arabī, 1983; vol. 2, ibid., 1985; vol. 3, ibid., 1986.

al-Ghīṭānī, Gamāl. Risālat al-bașā'`ir fì 'l-mașā’ir. Riwāyāt al-Hilāl 482. [Cairo]: Dār al-Hilāl, 1989.

al-Ghīṭānī, Gamāl. al-Zaynī Barakāt. Damaskus 1974. Eng. overs. Farouk Abdel Wahab, Zayni Barakat / Gamal al-Ghitani (London \& New York: Penguin Books, 1990, (1988)).

Gubayr, 'Abduh. Tahrīk al-qalb. Cairo: Dār Alif Yā', 1982.

Ibrāhīm, Jamīl 'Ațiyya. al-Nuzūl ilā' 'l-bahr. Kairo: Dār al-Mustaqbal al- 'Arabī, 1986.

Ibrāhīm, Șun ‘allāh. Dhāt. Cairo: Dār al-Mustaqbal al- 'Arabī, 1992. Eng. overs. Anthony Calderbank, Zaat (Cairo \& New York: American University in Cairo Press, 2001).

Ibrāhīm, Șun ‘allāh. Al-Lajna. Beirut: Dār al-Kalima li'l-Nashr, 1981. 2nd ed. Cairo: Mațbū'āt alQāhira, 1982. Eng. overs. Marie St. Germain og Charlene Constable, The Committee (Syracuse: Syracuse University Press, 2001). 
Jabrā, Jabrā Ibrāhīm. Al-Ghuraf al-ukhrā. Beirut: al-Mu'assasa al- 'Arabiyya li'l-Dirāsāt wa'l-Nashr, 1986.

Jabrā, Jabrā Ibrāhīm \& 'Abd al-Raḥmān Munīf. 'Ālam bi-lā kharā’iṭ. Beirut: al-Mu'assasa al'Arabiyya li'l-Dirāsāt wa'l-Nashr, 1982, 1992.

al-Kharrāț, Edward (Idwār). Turābuhā za'farān. Cairo: Dār al-Ādāb / Dār al-Mustaqbal al-'Arabī, 1985, 1991. English trans. Frances Liardet, City of Saffron (London: Quartet, 1989).

Khūrī, Ilyās. al-Jabal al-ṣaghīr. Beirut 1977. Eng. overs. Maia Tabet, Little Mountain / Elias Khoury (Manchester : Carcanet Press, 1989; forord af Edward W. Said).

Khūrī, Ilyās. Rihlat Ghāndī al-ṣaghīr. Beirut: Dār al-Ādāb, 1989. Eng. overs. Paula Haydar, The Journey of Little Gandhi (Minneapolis: Minnesota UP, 1994).

Khūrī, Ilyās. Bāb al-shams. 1998. Eng. overs. Humphrey Davies, Gate of the Sun / Elias Khoury (London: Harvill Secker, 2005).

Maḥfūz, Nagīb. 'Taḥt al-mizalla' (short story). In: Taḥt al-mizalla. Cairo 1969. Eng. overs. "Under the Bus Shelter", in: Flights of Fantasy. Arabic Short Stories, red./overs. C. Kassem \& M. Hashem, Cairo: Elias Modern Publishing House, 2. rev. udg. 1996, 85-92.

Mustaghānimī, Aḥlām. Dhākirat al-jasad, Beirut: Dār al-Ādāb, 1993. Eng. overs. Baria Ahmar Sreih, Memories in the Flesh (Cairo: AUC Press, 2000).

Pamuk, Orhan. Kara Kitap. Istanbul: Can, 1990, 1992. Eng. overs. Güneli Gün, The Black Book (New York: Farrar, Straus \& Giroux, 1994, and San Diego: Harcourt Brace \& Co., 1996). Dk. overs.: Den sorte bog, (Overs. Henning Goldbæk) København, 1996.

al-Qa 'īd, Yūsuf: Shakāwāa al-mișrī al-fașīh (The Complaints of the Eloquent Egyptian, 3 vols.). Beirut \& Kairo 1981-85.

al-Șāni', Rajā' 'Abdallāh. Banāt al-Riyāḍ. Beirut \& London: Saqi, 2005. Eng. overs. Rajaa Alsanea og Marilyn Booth, The Girls of Riyadh (London \& New York: Penguin Press, 2007).

al-Shaykh, Hanān. Hikāyat Zahra. Beirut: Dār al-Ādāb, 1980, 1989. Eng. overs. Peter Ford, The Story of Zahra (London \& New York: Quartet, 1986, 1993).

Shukrī, Muhammad. al-Khubz al-hāfì. Casablanca: by the author, 1982; 2nd ed. Tanja: n.p., 1983; 3rd ed. London/Beirut: Dār al-Sāqī, 1993. Eng. udg. på basis af 1. udg. Paul Bowles, For Bread Alone (London: P. Owen, [1973]; London: Grafton, 1987; og Saqi Books, 1993).

Shukrī, Muhammad. Zaman al-akhțā’': Sīra dhātiyya-riwā’’iyya. [Al-Dār al-Bayḍā']: Mațba 'at al-Najāh al-Jadīda, 1992.

\section{REFERENCER}

Anz, Thomas. 'Vorschläge zur Grundlegung einer Soziologie literarischer Normen', Internationales Archiv für Sozialgeschichte der deutschen Literatur 9 (1984): pp. 128-44.

Arabische Literatur, postmodern. Ed. Andreas Pflitsch, A. Neuwirth, B. Winckler. Munich: edition \& kritik, 2004. - English edition: Arabic Literature: Postmodern Perspectives, London: Saqi Books, planlagt til maj 2010.

Behzadi, Lale. Die qișșa-qașìda: Übersetzung und Untersuchung ausgewählter Kurzprosa der Sammlungen Madā'inu l-bad' und Gawāyātu z-zill von Nāșir al-Halawān̄i. Hildesheim; Zurich [etc.]: Georg Olms, 1996.

Fähndrich, Hartmut. 'Nachwort'. In: Jabrā, Jabrā Ibrāhīm. Das vierzigste Zimmer [Al-Ghuraf al$u k h r \bar{a}$ ], ovs. Heiko Wimmen. Basel: Lenos, 1999.

Falk, Walter. Handbuch der literarwissenschaftlichen Komponentenanalyse: Theorie, Operationen, Praxis einer Methode der neuen Epochenforschung. Beiträge zur neuen Epochenforschung 3. Frankfurt/ 
Main: Lang, 1983. Ny rev. udg: Handbuch der Komponentenanalyse: Erschließen von Sinn in Text und Epoche, Taunusstein: Vlg. Werner Imhof, 1996.

Falk, Walter. Die Ordnung in der Geschichte: Eine alternative Deutung des Fortschritts. Sachsenheim: Burg Vlg, 1985.

Falk, Walter. Parallele Ägypten: Die epochengeschichtlichen Verhältnisse in der ägyptischen und deutschen Literatur des 20. Jahrhunderts. In Zusammenarbeit mit den Mitgliedern des Projekts »Kairener Gegenwartsdiagnose«. Frankfurt/Main; Bern; New York; Nancy: Lang, 1984 [Beiträge zur neuen Epochenforschung; Bd. 4]

Falk, Walter. 'Das Sinnsystem der gegenwärtigen Periode: Präzisierungen der bisherigen Deutung (Zusammenfassung)'. Indlæg fremlagt på Marburger Kreis für Epochenforschungs (MKE-gruppen) årsmøde 16. sept. 1996.

Falk, Walter. Václav Havels Briefe aus dem Gefängnis: Wo der Mensch zu Hause ist - ein Dialog. Taunusstein: VerlagMar, 1994.

Fokkema, Douwe W. 'The Canon as an Instrument for Problem Solving'. In János Riesz, Peter Boerner og Bernhard Scholz, red., Sensus Communis: Contemporary Trends in Comparative Literature, pp. 245-54 (Tübingen: Narr, 1986).

Fontaine, Jean. 'Du neuf dans le roman égyptien', IBLA [revue de l'Institut des Belles Lettres Arabes, Tunis] 6, no. 181 (1998): pp. 27-47.

Fuhrmann, Manfred. Der europäische Bildungskanon des bürgerlichen Zeitalters. Frankfurt: Insel, 1999.

Furrer, Priska. 'Literatur und Hypertext: Nicht-Linearität im Kara Kitap des türkischen Autors Orhan Pamuk', Studia Iranica, Mesopotamica et Anatolica 1 (1994): pp. 167-77.

Gumbrecht, Hans Ulrich. In 1926: Living at the Edge of Time. Cambridge Mass. \& London: Harvard UP, 1997.

Guth, Stephan. Brückenschläge: Eine integrierte 'turkoarabische' Romangeschichte (Mitte 19. bis Mitte 20. Jhdt.). Literaturen im Kontext 14. Wiesbaden: Reichert Verlag, 2003.

Guth, Stephan. 'The Function of Sexual Passages in some Egyptian Novels of the 1980s'. In R. Allen, H. Kilpatrick og E. de Moor, red., Love and Sex in Modern Arabic Literature (London: Saqi Books, 1995), pp. 123-30.

Guth, Stephan. 'Jamāl al-Ghīțānī and The Epistle of Insights into the Destinies (1989): Authenticity as Counter-Strategy: Fighting Sadat's 'Open Door' Politics'. Planlagt til den eng. udg. af Arabische Literatur, postmodern, red. A. Pflitsch, A. Neuwirth \& B. Winckler (London \& Beirut: Saqi Books, 2009).

Guth, Stephan. 'The Simultaneity of the Non-Simultaneous: The Global Dimensions of Middle Eastern Literature (esp. in the 19th Century)'. In Chr. Szyska og F. Pannewick, red., Crossings and Passages in Genre and Culture, Literaturen im Kontext 15 (Wiesbaden: Reichert Verlag, 2003), 12137.

Guth, Stephan. A World Full of Secrets. The Hero as Detective in Two Novels from Egypt and Turkey. Indlæg holdt i 1994 og udgivet i hæfteform som Beirut Zokak el-Blat(t) [= Periodiske meddelelser fra Det Germanske Institut for Orientalske Studier i Beirut], no. 2, May 1996.

Guth, Stephan. Zeugen einer Endzeit: Fünf Schriftsteller zum Umbruch in der ägyptischen Gesellschaft nach 1970. Islamkundl. Untersuchungen 162. Berlin: Schwarz, 1992.

Guth, Stephan. 'Zwei Regionen - eine Literaturgeschichte? Zwei zeitgenössische Romane aus Ägypten und der Türkei und die Möglichkeit einer übergreifenden Periodisierung nahöstlicher Literaturen'. Die Welt des Islams 34 (1994): pp. 218-45. 
Hallaq, Boutros / Toelle, Heidi (eds., 2006): Histoire de la littérature arabe moderne, vol. 1, 1800-1945 (Paris: Sindbad).

Kindlers Neues Literatur Lexikon. 2. udg. Walter Jens (Studienausgabe der Originalausgabe 1988-92). 20 vols. München: Kindler (Stuttgart: J. B. Metzler, Oct. 2009; hovedredaktør Heinz Ludwig Arnold).

Kirchner, Mark. '»Das Schwarze Buch«: Orhan Pamuk und die türkische Postmoderne'. In Konrad Meisig, ed., Orientalische Erzähler der Gegenwart: Vorträge und Übersetzungen der Mainzer Ringvorlesung im Sommersemester 1998 (Wiesbaden: Harrassowitz, 1999), pp. 4363.

Metzler Lexikon Literatur- und Kulturtheorie: Ansätze, Personen, Grundbegriffe, ed. Ansgar Nünning. Stuttgart. Weimar: J. B. Metzler, 1998.

al-Nowaihi, Magda. 'Memory and Imagination in Edwar al-Kharrat's Turābuhā za'farān'. Journal of Arabic Literature 25 (1994): pp. 34-57.

Pflitsch, Andreas. 'Narration against Transitoriness and Temporality: Mythical Time Structure in Idwār al-Kharrāṭ’s Works'. In Angelika Neuwirth et al., red., Myths, Historical Archetypes and Symbolic Figures in Arabic Literature: Towards a New Hermeneutic Approach (= Referat af det internationale symposium i Beirut, 25.-30. juni 1996), Beiruter Texte und Studien 64 (Beirut: Orient-Institut; Stuttgart: Steiner, 1999), pp. 363-78.

Pflitsch, Andreas. Se også Arabische Literatur, postmodern.

Sagaster, Börte. 'Tendenzen in der zeitgenössischen türkischen Prosaliteratur'. Zeitschrift für Türkeistudien, 15 (2002), H. 1+2, 7-27.

Wielandt, Rotraud. 'Mystische Tradition und zeitgenössische Wirklichkeitserfahrung in Ğamāl al-Ġītānī's Kitāb at-tağalliyāt'. Asiatische Studien/Etudes Asiatiques 50 (1996): pp. 491-523.

Wielandt, Rotraud. 'Mystical and Mythical Journeys in Two Novels by Jamāl al-Ghīṭānî'. In A. Neuwirth et al., eds., Myths, Historical Archetypes and Symbolic Figures in Arabic Literature: Towards a New Hermeneutic Approach (= Referat af det internationale symposium i Beirut, 25.-30. juni 1996), pp. 467-80, Beiruter Texte und Studien 64 (Beirut: OrientInstitut; Stuttgart: Steiner, 1999). 